\title{
Adipose Tissue-Derived Stem Cells and the Importance of Animal Model Standardization for Pre-Clinical Trials
}

\author{
Marilia Sanches Santos Rizzo Zuttion ${ }^{1}$, Cristiane Valverde Wenceslau², \\ Pedro A. Lemos ${ }^{3}$, Celso Takimura ${ }^{4}$, Irina Kerkis ${ }^{5}$
}

\begin{abstract}
Stem cells are undifferentiated cells and can self-renew and differentiate into various cell types, besides having immunomodulating properties and paracrine effects in response to tissue injury, and may therefore treat injuries and diseases or even replace damaged or lost cells. Adipose tissue is an attractive source of adult stem cells, since the human body has a large reserve that is obtained in large amounts by minimally invasive methods. Interest in these cells has been increasing steadily due to their properties and possible applications in regenerative medicine and cell therapy. A large part of these investigations are focused on cardiovascular diseases, which are a leading cause of morbidity and mortality worldwide. Although in recent years treatments have advanced in cardiology, the development of new therapies to recover the damaged tissue still remains one of the main goals of cardiac research. However, to achieve effective results, in vivo and in vitro animal models for preclinical studies and consequently for application in humans must be standardized. The development of preclinical models in large animals requires the use of well-characterized animal cell lines, similar to human cells, and the use of the porcine model represents a great advantage for preclinical translational research.
\end{abstract}

DESCRIPTORS: Stem cells. Adipose tissue. Cardiovascular diseases. Swine. Models, animal.
RESUMO

\section{Células-Tronco de Tecido Adiposo e a Importância da Padronização de um Modelo Animal para Experimentação Pré-Clínica}

As células-tronco são células indiferenciadas, capazes de se autorrenovar e de se diferenciarem em diversos tipos celulares, além de apresentarem propriedades imunomoduladoras e efeitos parácrinos mediante injúria tecidual, podendo, dessa forma, tratar lesões e doenças ou ainda substituir células danificadas ou perdidas. Dentre as fontes de células-tronco adultas, o tecido adiposo é uma fonte atrativa, pois o organismo humano possui grande reserva desse tecido, que, por sua vez, é obtido em grandes quantidades por meio de métodos pouco invasivos. O interesse nessas células vem aumentando constantemente devido a suas propriedades e possíveis aplicações na medicina regenerativa e terapia celular. Grande parte dessas pesquisas está voltada para doenças cardiovasculares, que são a principal causa de morbidade e mortalidade em todo o mundo. Embora nos últimos anos, os tratamentos em cardiologia tenham avançado, o desenvolvimento de novas terapias que recuperem o tecido danificado ainda permanece como um dos objetivos principais das pesquisas cardíacas. Porém, para obter resultados eficazes, é necessária a padronização de modelos animais in vivo e in vitro para estudos pré-clínicos e, consequentemente, a aplicação em humanos. O desenvolvimento de modelos pré-clínicos em animais de grande porte exige o uso bem caracterizado de linhagens de células animais semelhantes aos seus equivalentes humanos. O modelo suíno representa uma grande vantagem para a investigação translacional pré-clínica.

DESCRITORES: Células-tronco. Tecido adiposo. Doenças cardiovasculares. Suínos. Modelos animais.

\footnotetext{
1 Postgraduate (Doctorare) at the Biology Department of Estrutural e Funcional da Universidade Federal de São Paulo. São Paulo, SP, Brazil. 2 Postgraduate at the Structual and Funcional Biology Department of Universidade Federal de São Paulo. São Paulo, SP, Brazil.

3 Full professor. Director of the Hemodynamics and Interventional Cardiology Service of Instituto do Coração do Hospital das Clínicas da Faculdade de Medicina da Universidade de São Paulo. São Paulo, SP, Brazil.

${ }^{4}$ Doctor. Researcher Physician at Instituto do Coração do Hospital das Clínicas da Faculdade de Medicina da Universidade de São Paulo. São Paulo, SP, Brazil.
}

Correspondence to: Irina Kerkis. Laboratório de Genética do Instituto Butantan - Av. Vital Brasil, 1.500 - São Paulo, SP, Brazil - CEP 05503-900 E-mail: ikerkis@butantan.gov.br

Received on: 3/28/2013 • Accepted on: 8/8/2013

Source offinancial support: Marilia Sanches Santos Rizzo Zuttion receives a grant from the Coordenação de Aperfeiçoamento de Pessoa de Nível Superior (CAPES) 
S tem cells (SCs) are undifferentiated cells that can self-renew and differentiate into many cell types. In these processes of self-renewal and differentiation, the SCs can undergo two different types of division: (1) symmetrical division, in which the SC generates a new SC cell and a progenitor cell, and (2) asymmetrical division, in which the SC generates differentiated cells. ${ }^{1}$ This process occurs while maintaining tissue homeostasis and the active SC niche. The niches are physiological microenvironments, consisting of specialized cells that signal and provide molecules on the cell surface to control the rate of proliferation of SCs, determining the differentiation of progenitor cells and protecting SCs from apoptosis. This reciprocal interaction between the SCs and the niche occurs in the early stages of embryonic development and is maintained during adulthood, and is essential for ontogeny and tissue repair. ${ }^{2}$

SCs are divided into two main types, according to their origin and plasticity. SCs may be of embryonic origin, that is, are isolated from the zygote or the inner cell mass of the blastocyst, or they may be derived from the adult organism. Concerning the capacity of these cells to originate organism tissues, embryonic stem cells (ESCs) are classified as pluripotent, i.e., they are capable of generating all body cell types; whereas adult SCs (ASCs) have a more restricted differentiation potential, and are classified as multipotent.

ASCs were first described by Friendestein in 1970, who isolated in vitro stromal cells from bone marrow of mice. In that study, he demonstrated the morphological characteristics of cell expansion and differentiation. ${ }^{3}$ Subsequently, in different culture conditions, it was observed that bone marrow ASCs were able to differentiate into osteoblasts, chondrocytes, and adipocytes. ${ }^{4}$ Based on this capacity to differentiate into different cell types, Caplan proposed in 1991 the term "mesenchymal stem cell" (MSC). ${ }^{5}$

The most studied source of MSCs is the bone marrow. MSCs from bone marrow, which represent a rare subpopulation $(<0.01 \%$ of the mononuclear cells from bone marrow) are a group of clonogenic cells, found in the bone marrow stroma and capable of differentiating not only into cells of mesodermal origin, but also into other non-mesodermal cell types, such as the neural and the hepatocytes. ${ }^{6}$

ASCs are known as multipotent, and differently from what was originally believed, they are not involved only in the process of repair and homeostasis in tissues from which they are isolated, but also have several paracrine effects that contribute to the recovery and regeneration of other cell types and tissues in the body, ${ }^{7}$ as these cells produce and secrete a variety of cytokines, chemokines, and growth factors, which act in a paracrine manner in in vivo tissue regeneration. ${ }^{8}$

\section{CELL CHARACTERIZATION}

For a cell population to be considered SCs, it must meet at least three requirements according to the International Society for Cellular Therapy:

1. They have to be plastic-adherent, while maintained in culture conditions;

2. They have to be positive for CD105, CD73, and CD90, and negative for CD45, CD34, CD14, CD11b, CD79, or CD19 and HLA-DR. ${ }^{9}$ However, depending on the source from which they are obtained, the methods of cell isolation, and characteristics of the culture, the expression of these markers can occur differently. ASCs can also express other surface proteins such as CD44, CD71 (transferrin receptor), Stro-1 and fibronectin, vimentin, and CD73 (ecto-5'-nucleotidase, SH3, and SH4), among others. ${ }^{10,11}$ More studies are still needed to elucidate the expression variability of severalmarkers;

3. They have to be capable of differentiating into osteoblasts, chondrocytes, and adipocytes. ${ }^{9}$

\section{MSC SOURCES}

As previously stated, the bone marrow is the most common source of MSCs, ${ }^{12}$ but similar populations have also been obtained from other sources, such as umbilical cord blood, placenta, amniotic fluid, dermis, liver, spleen, dental pulp, ${ }^{14}$ and adipose tissue. ${ }^{15}$

Among these sources, the adipose tissue stands out, which offers more advantages compared to other sources, due to its low risk for donors, higher number of MSCs (it is possible to collect $100 \mathrm{~mL}$ from $1 \mathrm{~L}$ of adipose tissue), and capability of maintaining their proliferative potential for eight to ten passages without any detectable deterioration in their capacity of self-renewal, in addition to the absence of immunologic rejection. ${ }^{16}$

\section{THE ADIPOSE TISSUE}

Adipose tissue has mesodermal origin and contains a heterogeneous stromal cell population. The mesoderm arises during gastrulation as a medial layer between the endoderm and ectoderm. The embryonic mesoderm gives origin to several types of muscles - including the heart, all connective tissue, blood vessels, blood cells, and lymphatic vessels. ${ }^{15}$ Historically, adipose tissue was considered a metabolic reservoir for storage and release of energy substrates in the form of triglycerides and cholesterol, as well as fat-soluble vitamins. In the mid-1980s, this concept was modified, based on the identification of its role in sexual physiology through sexual steroids. ${ }^{17}$ The adipose tissue is a component of connective tissue with important functions, such as providing rigidity and resistance to tissues, maintaining thermal homeostasis, and assisting in visceral static. In 
mammals, the predominant type of adipose tissue is the white type, compared to brown adipose tissue, which is found in neonates, but is virtually absent in adults. ${ }^{18}$ This tissue is distributed in the body as subcutaneous white adipose tissue and white visceral adipose tissue, consisting of mature adipocytes, preadipocytes, fibroblasts, smooth muscle vascular cells, endothelial cells, resident monocytes, and macrophages and lymphocytes. ${ }^{19}$

According to Zannetino et al., ${ }^{2}$ the niche of MSCs in adipose tissue is located in the perivascular region, and consists of blood vessels in association with connective tissue, adipose stromal tissue, and many progenitor cells and SCs (Figure 1). It may be stated that the adipose tissue SC niche is perivascular. Although the term "perivascular" means "around blood vessels", adipose tissue SCs are also found within the vessels, as a part of the blood vessel wall components. However, due to the lack of specific markers, the exact location and cell identity are still elusive.

The vascular network plays a role in adipogenesis. During embryonic development, the formation of capillaries is a decisive and specific phase in the development of adipose lobules, and an adequate vascularization is required for optimal functioning of the adipose tissue as a metabolic and endocrine organ. In addition, the adipogenic lineage cells secrete potent angiogenic factors, such as monobutyrin, vascular endothelial growth factor, leptin, and adiponectin. Finally, anti-angiogenic factors promote the loss of adipose tissue, thereby demonstrating the importance of angiogenesis for the maintenance of adipogenesis. ${ }^{20-22}$ However, large quantities of SCs can be isolated from this vascular fraction through the enzymatic digestion method.

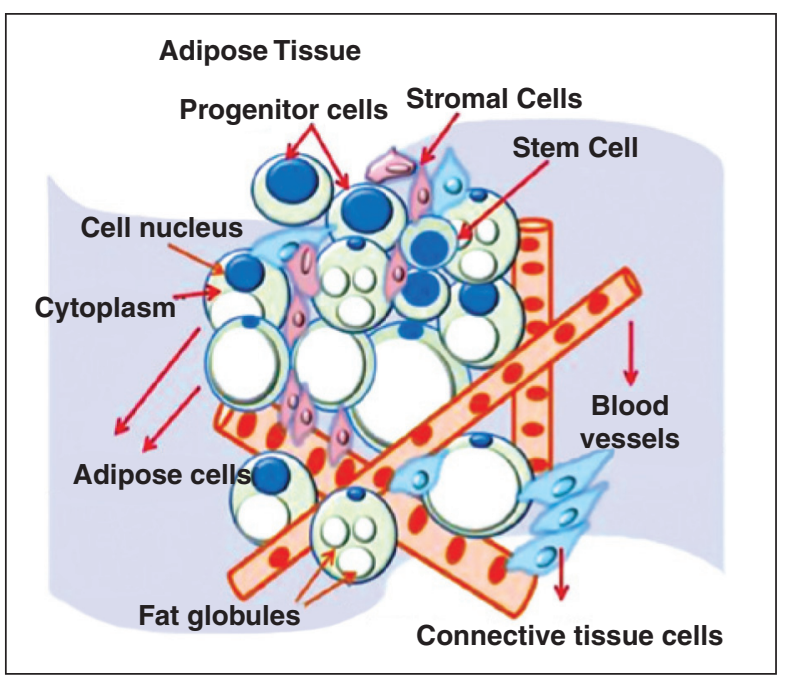

Figure 1. Figure illustrating adipose tissue-derived adult stem cell niche. Source: Irina Kerkis

\section{ISOLATION OF MCS FROM ADIPOSE TISSUE}

In 1964, Martin Rodbell ${ }^{23}$ established the in vitro isolation method of mature adipocytes and adipogenic progenitor cells from adipose tissue of rats. In his protocol, the tissue was fragmented and digested with type I collagenase enzyme at $37^{\circ} \mathrm{C}$ and the material was then centrifuged. The supernatant contained mature adipocytes and the pellet had components of vascular stromal fraction, including adipocyte progenitor cells and hematopoietic lineage cells.

As in many fields with a rapid development, a number of names have been used for describe the adherent cell population, isolated from the enzymatic digestion by collagenase from adipose tissue, such as lipoblast, pericytes, pre-adipocyte, processed lipoaspirate, adipose tissue-derived stromal SC, adipose tissue-derived ASC, adipose tissue-derived stromal adult cell, adipose tissuederived multipotent SC, and adipose tissue MSC (Figure $2 \mathrm{~A}$ to $2 \mathrm{C}$ ). The International Fat Applied Technology Society (IFATS) proposed a standardized nomenclature in Pittsburgh in 2004, adopting the term ASC, or adipose stem cell, to refer to the population of adherent multipotent cells isolated from the vascular stromal fraction. ${ }^{24}$ The adipose tissue MSCs were isolated and characterized in humans and in animal species. ${ }^{13,25-30}$

\section{ADIPOSE TISSUE MSCS}

Similarly to the bone marrow, the adipose tissue MSCs have a broad differentiation potential in several different cell types, such as adipogenic, chondrogenic, osteogenic, (Figure 2D to 2F), myogenic, angiogenic, neurogenic, myogenic and cardiomiogenic. ${ }^{31}$ Nevertheless, the isolation success rate is $100 \%$ and the adipose tissue yield is 40 times higher than that of bone marrow. ${ }^{32}$ Furthermore, the quantity of cells does not appear to decrease with age, making this type of cell attractive for the isolation of MSCs and progenitor cells. ${ }^{33}$

The MSCs have the capacity to accumulate around inflammatory processes when administered in vivo, due to their chemotactic properties. Therefore, these cells can be used in several areas, such as in regenerative therapy. ${ }^{7}$ Currently, cells with characteristics similar to those of human MSCs were isolated in vitro from several animals (pigs, ${ }^{34-38}$ dogs, ${ }^{39}$ sheep ${ }^{40}$ ). These animals are often used in regenerative medicine research as animal models for osteoarticular diseases, ${ }^{41}$ spinal cord injury, ${ }^{42}$ and myocardial infarction. ${ }^{37}$

\section{REGENERATIVE MEDICINE}

As shown above, adipose-tissue SCs exhibit abundant capacity of expansion in vitro and, more importantly, can originate cells of different cell lineages and even cardiomyocytes, $^{32,43}$ in addition to the absence of ethical 

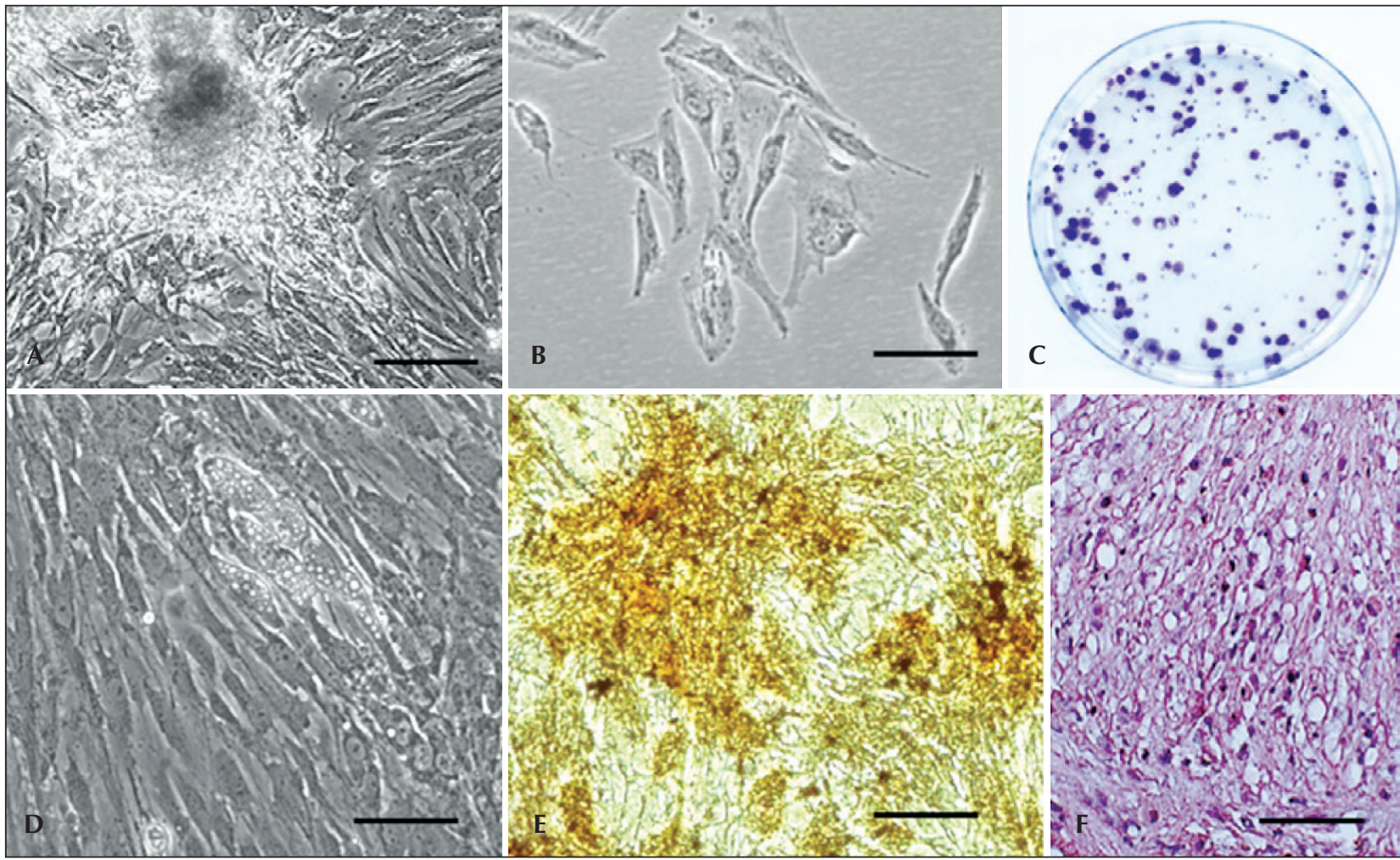

Figure 2 - Swine adipose tissue-derived stem cells. (A) Isolation of stem cells from adipose tissue. (B) Morphology of adipose tissue-derived stem cells. (C) Colony-forming unit assay in adipose tissue-derived stem cells. (D) Adipogenic differentiation. Note the cells with lipid droplets. (E) Osteogenic differentiation (von Kossa staining); mineralization can be observed. (F) Hematoxylin-eosin staining demonstrating the chondrogenic differentiation. Scale bars: $A=20 \mathrm{~mm}$; $B$ to $F=10$ micrometers. $A, B$, and $D=$ phase contrast. $C$, $E$, and $F=$ optical microscopy. Source: Zuttion et al., 2013 (unpublished data).

questions regarding their use. Therefore, adipose tissue has become a very attractive source of MSCs for regenerative medicine, and cardiology is one of the areas in which these cells are very frequently employed. ${ }^{6}$

The leading cause of death worldwide due to non communicable diseases is cardiovascular disease (48\%), such as myocardial infarction and congestive heart failure. ${ }^{44}$ Other diseases also cause myocardial dysfunction, such as Chagas disease and other cardiomyopathies. ${ }^{45}$

Advances in the treatment of cardiovascular diseases are due, in part, from the development of coronary revascularization techniques, and pacemaker and defibrillator implantation. With the exception of heart transplantation, these treatment options are limited by their incapacity to substitute lost cardiomyocytes and myocardial scars, and this is aggravated by the incapacity of the heart to replace its cell mass through self-renewal. New treatment approaches are necessary; ${ }^{46}$ alternatively, SC therapy has been proposed to generate new cardiomyocytes. ${ }^{47}$ Some studies have demonstrated the capacity of adipose tissue and bone marrow MSCs to differentiate into cardiomyocytes. ${ }^{48-50}$ However, some studies have shown that the differentiation of MSCs into cardiomyocytes, when injected into the heart muscle, is arare event, demonstrating that the MSCs are not capable of generating cardiomyocytes in sufficient amounts to repair myocardial injury. ${ }^{51}$ However, the MSCs have not only an autocrine, but also a paracrine property, that is, when the MSCs are injected, they secrete factors (vascular endothelial growth factor, basic fibroblast growth factor, hepatocyte growth factor, insulin-like growth factor 1, and adrenomedullin), which play an anti-apoptotic, pro-angiogenic role and have an endogenous reparative effect, in addition to exerting aparacrine action directly on cardiomyocytes, increasing their rate of survival. ${ }^{52}$

Another important biological process influenced by MSCs through their paracrine effects is neovascularization. Recent preclinical studies with femur fractures in rats have demonstrated the angiogenic potential of SCs derived from human adipose tissue. After ASC transplantation, an increase of angiogenesis 
and neovascularization around the area of endochondral ossification occurred, as well as a significant increase of capillary density. ${ }^{53}$ In another study using pigs as an animal model, it was shown that eight weeks after intramyocardial MSC transplantation, there was improvement in left ventricular function. The researchers observed that, after the first week of transplantation, there was improvement in myocardial blood flow during diastole, which was directly related to blood vessel size increase. These results indicated the process of neovascularization as a consequence of significant cardiomyogenesis. ${ }^{54}$ This is due to the production and secretion by MSCs of factors such as nitric oxide, vascular endothelial growth factor, basic fibroblast growth factor, angiopoietin, and hepatocyte growth factors, among others. The action of these factors leads to migration and proliferation of endothelial cells and vascular smooth muscle cells, as well as increase and maturation of vessels and extracellular matrix synthesis. Thus, the MSCs would improve capillary density and act in the formation of collateral vessels. ${ }^{7}$ However, despite much research on the differentiation potential of these cells in cardiomyocytes, studies are still necessary to understand these mechanisms.

\section{ANIMAL MODEL USED IN SC RESEARCH}

Since many years ago until the present day, several species of animals have been used as experimental subjects in scientific research, aiming to discover prophylactic or treatment measures for many diseases. ${ }^{55,56}$

Around 1865, Claude Bernard ${ }^{57}$ started using animals as a study model for transposition of acquired knowledge to understand human physiology. In his study, Bernard ${ }^{57}$ sought physical and chemical changes that caused alterations in animals similar to human diseases. Small animals (mice, rats, hamsters, or gerbils) comprise more than $90 \%$ of the total species used in laboratories, ${ }^{48}$ but the ideal model for use in research would be the one that resembled the human being in their physiological, anatomical, and organic characteristics, which impacts the effectiveness of the obtained conclusions. ${ }^{57}$

Given this fact, many results of studies with SCs are inconclusive due to the practice of xenotransplantation (transplantation of organs or cells from different species), because these cells are usually isolated from human beings ${ }^{58,59}$ and transplanted to other species, which complicates the study and understanding of their action in the body. Furthermore, few animals are similar to the human organism, which further reduces the understanding of SCs. Thus, it would be ideal to have an animal model that was similar to humans in anatomy, physiology and pathophysiology. According to Bustard and McClellan, ${ }^{60}$ the pig (Sus scrofa domesticus) has similarities with humans regarding odontology, renal morphology and physiology, visual acuity, eye structure, skin physiology and morphology, cardiovascular physiology and anatomy, digestive physiology and anatomy, and immunology. These similarities are more distant in other models, such as dogs, rats, mice, and other species used in research. ${ }^{56}$ According to Tumbleson, ${ }^{61}$ pigs are an effective model for studies in biomedical research because, in addition to presenting structures and functions similar to that of the human, it has similarity regarding size, diet pattern, digestive physiology, dietary habits, kidney structure and function, lung vascular structure, distribution of coronary arteries, propensity for obesity, respiratory frequency, and social behavior; and it is a flexible animal model to determine the effects of acute and chronic exposures to alcohol, caffeine, tobacco, food additives, and environment pollutants.

Regarding adipose tissue MSCs, the pig model would be ideal, because in addition to all the similarities with human being, this animal has a large reserve of adipose tissue, ${ }^{61}$ facilitating MSC isolation from adipose tissue and autologous or heterologous transplantation (transplantation of organs or cells to the same species), in order to evaluate the mechanism of action of these cells and human MSCs.

\section{SWINE ADIPOSE TISSUE SCs}

Several authors have performed the isolation of adipose tissue-derived SC in pigs. Such cells showed potential to differentiate into different mesodermal lineages, such as bone, cartilage, fat, muscle, and cardiomyocytes, and expressed different SC markers, showing similarities with human adipose tissue-derived MSCs. ${ }^{34-38}$ Interestingly, pigs are already widely used in this field regarding endovascular device implantation, such as stents. ${ }^{62,63}$ However, it is a good preclinical model to test the effect of SCs specifically in the area of SCs applied to cardiovascular diseases.

Moreover, these cells isolated from pigs have been partially characterized regarding the expression of MSC markers, and therefore it is difficult to compare the benefits of these cells in an organism not similar to the human body.

\section{FINAL CONSIDERATIONS}

The MSCs isolated from adipose tissue have a wide differentiation potential and can be easily obtained in large quantities through minimally-invasive and low-pain methods. Furthermore, these cells are able to promote the immunomodulation of the immune system and have a paracrine effect capable of mobilizing molecules to regenerate injured tissue. However, much of the research on SCs is limited, due to the use of xenotransplantation and the lack of standardization of animal models that are anatomically and physiologically close to that 
of the human body, for instance, pigs. Therefore, a greater knowledge of the action mechanism of these cells is necessary, in a physiological environment that reproduces the human organism. This fact has caused some clinical and therapeutic applications of SC to remain uncertain. In summary, the expectation of regenerative medicine based on SC use depends on the knowledge of the mechanism of these cells and their effects on the body, as well as of the molecules, factors, and signalling cascades that control cell survival and proliferation - through contact with SCs. Therefore, the applicability of SCs depends mostly on the use of suitable models and well characterized SCs. Multiple solutions are likely to emerge from growing technologies in the SC and regenerative medicine area. Numerous innovations will change the practice of medicine through the recognition that living cells are able to perform a series of functions that drugs cannot provide.

\section{CONFLICTS OF INTEREST}

The authors declare no conflicts of interest.

\section{REFERENCES}

1. Thomson JA, Itskovitz-Eldor J, Shapiro SS, Waknitz MA, Swiergiel JJ, Marshal VS, et al Embryonic stem cell lines derived from hum an blastocysts. Science. 1998;282(5391):1145-47.

2. Zannettino AC, Paton S, Arthur A, Khor F, Itescu S, Gimble JM, et al. Multipotential human adipose-derived stromal stem cells exhibit a perivascular phenotype in vitro and in vivo. J Cell Physiol. 2008;214(2):413-21.

3. Friedenstein AJ, Chailakhjan RK, Lalykina KS. The development of fibroblast colonies in monolayer cultures of guinea-pig boné marrow and spleen cells. Cell Tissue Kinet. 1970;3(4):393-403.

4. Dennis JE, Charbord P. Origin and differentiation of human and murine stroma. Stem Cells. 2002;20(3):205-14.

5. Caplan AI. Mesenchymal stem cells. J Orthop Res. 1991;9(5):641-50.

6. Blydlowski SP, Debes AA, Maselli LMF, Janz FL. Características biológicas das células-tronco mesenquimais. Rev Bras Hematol Hemoter. 2009; 31 Supl.1:25-35.

7. Souza CF, Napoli P, Han SW, Lima VC, Carvalho ACC. Células-tronco mesenquimais: células ideais para a regeneração cardíaca. Rev Bras Cardiol Invasiva. 2010;18(3):344-53. 8. Caplan AI, Dennis JE. Mesenchymal stem cells as trophic mediators. J Cell Biochem. 2006;98(5):1076-84.

9. Dominici M, Le Blanc K, Mueller I, Slaper-Cortenbach I, Marini F, Krause D, et al. Minimal criteria for defining multipotent mesenchymal stromal cells. The International Society for Cellular Therapy position statement. Cytotherapy. 2006;8(4):315-7.

10. Gronthos S, Franklin DM, Leddy HA, Robey PG, Storms RW, Gimble JM. Surface protein characterization of human adipose tissue-derived stromal cells. J Cell Physiol. 2001;189(1):54-63.

11. Sabatini F, Petecchia L, Tavian M, Jodon de Villeroché V, Rossi GA, Brouty-Boyé D. Human bronchial fibroblasts exhibit a mesenchymal stem cell phenotype and multilineage differentiating potentialities. Lab Invest. 2005;85(8):962-71.

12. Conget PA, Minguell JJ. Phenotypical and functional properties of human bone marrow mesenchymal progenitor cells. J Cell Physiol. 1999;181(1):67-73.
13. Bianco P, Cossu G. Uno, nessuno e centomila: searching for the identity of mesodermal progenitors. Exp Cell Res. 1999;251(2):257-63.

14. Kerkis I, Caplan AI. Stem cells in dental pulp of deciduous teeth. Tissue Eng Part B Rev. 2012;18(2):129-38.

15. Zuk PA, Zhu M, Mizuno H, Huang J, Futrell JW, Katz AJ, et al. Multilineage cells from human adipose tissue: implications for cell-based therapies. Tissue Eng. 2001;7(2):211-28.

16. Gruber HE, Somayaji S, Riley F, Hoelscher GL, Norton HJ, Ingram J, et al. Human adipose-derived mesenchymal stem cells: serial passaging, doubling time and cell senescence. Biotech Histochem. 2012;87(4):303-11.

17. Rada T, Reis RL, Gomes ME. Adipose tissue-derived stem cells and their application in bone and cartilage tissue engineering Tissue Eng Part B Rev. 2009;15(2):113-25.

18. Lin CS, Xin ZC, Deng CH, Ning H, Lin G, Lue TF. Defining adipose tissue-derived stem cells in tissue and in culture. Histol Histopathol. 2010;25(6):807-15.

19. Schäffler A, Büchler C. Concise review: adipose tissue-derived stromal cells basic and clinical implications for novel cellbasedtherapies. Stem Cells. 2007;25(4):818-27.

20. Lin G, Garcia M, Ning H, Banie L, Guo YL, Lue TH, et al. Tissue-engineered skin containing mesenchymal stem cells improves burn wounds. Artif Organs. 2008;32(12):925-31.

21. Rupnick MA, Panigrahy D, Zhang CY, Dallabrida SM, Lowell $\mathrm{BB}$, Langer $\mathrm{R}$, et al. Adipose tissue mass can be regulated through the vasculature. Proc Natl Acad Sci U S A. 2002;99(16): 10730-5.

22. Ouchi N, Kobayashi H, Kihara S, Kumada M, Sato K, Inoue T, et al. Adiponectin stimulates angiogenesis by promoting crosstalk between AMP-activated protein kinase and Akt signaling in endothelial cells. J Biol Chem. 2004;279(2):1304-9.

23. Rodbell M. Localization of lipoprotein lipase in fat cells of rat adipose tissue. J Biol Chem. 1964;239:753-5.

24. Daher SR, Johnstone BH, Phinney DG, March KL. Adipose stromal/stem cells: basic and translational advances: the IFATS collection. Stem Cells. 2008;26(10):2664-5.

25. Kingham PJ, Kalbermatten DF, Mahay D, Armstrong SJ, Wiberg M, Terenghi G. Adipose-derived stem cells differentiate into a Schwann cell phenotype and promote neurite outgrowth in vitro. Exp Neurol. 2007;207(2):267-74.

26. Yoshimura $H$, Muneta $T$, Nimura A, Yokoyama A, Koga $H$, Sekiya I. Comparison of rat mesenchymal stem cells derived from bone marrow, synovium, periosteum, adipose tissue, and muscle. Cell Tissue Res. 2007;327(3):449-62.

27. Peptan IA, Hong L, Mao JJ. Comparison of osteogenicpotentials of visceral and subcutaneous adipose-derived cells of rabbits. Plast Reconstr Surg. 2006;117(5):1462-70.

28. Torres FC, Rodrigues CJ, Stocchero IN, Ferreira MC. Stem cells from the fat tissue of rabbits: an easy-to-find experimental source. Aesthetic Plast Surg. 2007;31(5):574-8.

29. Mambelli LI, Santos EJ, Frazão PJ, Chaparro MB, Kerkis A, Zoppa AL, et al. Characterization of equine adipose tissuederived progenitor cells before and after cryopreservation. Tissue Eng Part C Methods. 2009;15(1):87-94.

30. Mohammadi-Sangcheshmeh A, Shafiee A, Seyedjafari E, Dinarvand P, Toghdory A, Bagherizadeh I, et al. Isolation, characterization, and mesodermic differentiation of stem cells from adipose tissue of camel (Camelus dromedarius). In Vitro Cell Dev Biol Anim. 2013;94(2):147-54.

31. Strem BM, Hicok KC, Zhu M, Wulur I, Alfonso Z, Schreiber RE, et al. Multipotential differentiation of adipose tissue-derived stem cells. Keio J Med. 2005;54(3):132-41. 
32. Kern S, Eichler H, Stoeve J, Kluter H, Bieback K. Comparative analysis of mesenchymal stem cells from bone marrow, umbilical cord blood, or adipose tissue. Stem Cells. 2006;24(5): 1294-301.

33. DiMuzio P, Tulenko T. Tissue engineering applications to vascular bypass graft development: the use of adipose derived stem cells. J Vasc Surg. 2007;45 Suppl A:A99-103.

34. Qu CQ , Zhang GH, Zhang LJ , Yang GS. Osteogenic and adipogenic potential of porcine adipose mesenchymal stem cells. In Vitro Cell Dev Biol Anim. 2007;43(2)95-100.

35. Ringe J, Kaps C, Schmitt B, Büscher K, Bartel J, Smolian H, et al. Porcine mesenchymal stem cells. Induction of distinct mesenchymal cell lineages. Cell Tissue Res. 2002;307(3): 321-7.

36. Arrigoni E, Lopa S, de Girolamo L, Stanco D, Brini AT. Isolation, characterization and osteogenic differentiation of adiposederived stem cells: from small to large animal models. Cell Tissue Res. 2009;338(3):401-11.

37. Casado JG, Gomez-Mauricio G, Alvarez V, Mijares J, Tarazona R, Bernad A, et al. Comparative phenotypic and molecular characterization of porcine mesenchymal stem cells from differentsources for translational studies in a large animal model. Vet Immunol Immunopathol. 2012;147(1-2):104-12.

38. Wang KH, Kao AP, Wangchen H, Wang FY, Chang $\mathrm{CH}$, Chang CC, et al. Optimizing proliferation and characterization of multipotent stem cells from porcine adipose tissue. Biotechnol Appl Biochem. 2008;51(Pt 4):159-66.

39. Neupane M, Chang CC, Kiupel M, Yuzbasiyan-Gurkan V. Isolation and characterization of canine adipose-derived mesenchymal stem cells. Tissue Eng Part A. 2008;14(6):1007-15.

40. Fadel L, Viana BR, Feitosa ML, Ercolin AC, Roballo KC, Casals JB, et al. Protcols for obtainment and isolation of two mesenchymal stem cell sources in sheep. Acta Cir Bras. $2011 ; 26(4): 267-73$.

41. Feitosa ML, Fadel L, Beltrão-Braga PC, Wenceslau CV, Kerkis I, Kerkis A, et al. Successful transplant of mesenchymal stem cells in induced osteonecrosis of the ovine femoral: preliminary results. Acta Cir Bras. 2010;25(5):416-22.

42. Lim JH, Byeon YE, Ryu HH, Jeong YH, Lee $Y W, K$ Kim $W H$, et al. Transplantation of canine umbilical cord blood-derived mesenchymal stem cells in experimentally induced spinalcord injured dogs. J Vet Sci. 2007;8(3):275-82.

43. Phinney DG, Prockop DJ. Concise review: mesenchymal stem/multipotent stromal cells: the state of transdifferentiation and modes of tissue repair-current views. Stem Cells. 2007;25(11):2896-902.

44. World Health Organization. Global health risks: mortality and burden of disease attributable to selected major risks [Internet]. Geneva; WHO; 2009 [cited 2013 Mar 19]. Available from: http://www.who.int/healthinfo/global_burden_disease/ GlobalHealthRisks_report_Front.pdf

45. Arom KV, Ruengsakulrach $P$, Jotisakulratana V. Intramyocardial angiogenic cell precursor injection for cardiomyopathy. Asian Cardiovasc Thorac Ann. 2008;16(2):143-8.

46. Psaltis PJ, Gronthos S, Worthley SG, Zannettino ACW. Cellular therapy for cardiovascular disease. Part 1 - preclinical insights. Clin Med Cardiol. 2008;2:125-38.
47. Rajala K, Pekkanen-Mattila M, Aalto-Setälä K. Cardiac differentiation of pluripotent stem cells [images]. Stem Cells Int. 2011;2011:383709.

48. Tokcaer-Keskin Z, Akar AR, Ayaloglu-Butun F, Terzioglu-Kara E, Durdu S, Ozyurda U, et al. Timing of introduction of cardiomyocyte differentiation for in vitro cultured mesenchyma stem cells: a perspectivefor emergencies. Can J Pysiol Pharmacol.2009;87(2):143-50.

49. Choi YS, Dusting GJ, Stubbs S, Arunothayaraj S, Han XL, Collas P, et al. Differentiation of human adiposederived stem cells into beating cardiomyocytes. J Cell Mol Med. 2010;14(4):878-89.

50. Xing Y, Lv A, Wang L, Yan X. The combination of angiotensin II and 5-azacytidine promotes cardiomyocyte differentiation of rat bone marrowmesenchymal stem cells. Mol Cell Biochem. 2012;360(1-2):279-87.

51. Breitbach M, Bostani T, Roell W, Xia Y, Dewald O, Nygren $J M$, et al. Potential risks of bone marrow cell transplantation into infarcted hearts. Blood. 2007;110(4):1362-9.

52. Gnecchi M, Zhang Z, Ni A, Dzau VJ. Paracrine mechanisms in adult stem cell signaling and therapy. Circ Res. 2008; 103(11):1204-19.

53. Shoji T, li M, Mifune Y, Matsumoto T, Kawamoto A, Kwon SM et al. Local transplantation of human multipotent adiposederived stem cells accelerates fracture healing via enhanced osteogenesis and angiogenesis. Lab Invest. 2010;90(4):637-49.

54. Schuleri KH, Amado LC, Boyle AJ, Centola M, Saliaris AP, Gutman MR, et al. Early improvement in cardiac tissue perfusion due to mesenchymal stem cells. Am J Physiol Heart Circ Physiol. 2008;294(5):H2002-11.

55. Chorilli M, Michelin DC, Salgado HRN. Animais de laboratório: o camundongo. Rev Ciênc Farm Básica Apl. 2007;28(1):11-23.

56. Mariano M. Minisuíno (minipig) na pesquisa biomédica experimental: o Miniping br1. Acta Miniature swine (minipig) in biomedical experimental research: the Minipig br1. Acta Cir Bras. 2003;18(5):387-91.

57. Bernard C. An introduction to the study of experimental medicine (1865) [Internet]. [cited 2013 July 24]. Available from: http://campus.udayton.edu/ hume/Bernard/bernard.htm

58. Schanaider A, Silva PC. Uso de animais em cirurgia experimental. Acta Cir Bras. 2004;19(4):380-5.

59. Li J, Ezzelarab MB, Cooper DK. Do mesenchymal stem cells function across species barriers? Relevance for xenotransplantation. Xenotransplantation. 2012;19(5):273-85.

60. Bustard LK, McClellan RO. Use of pigs in biomedical research. Nature. 1965;208:531-5.

61. Tumbleson ME. Swine in biomedical research. New York: Plenum Press; 1986

62. Lemos PA, Laurindo FRM, Morato SP, Takimura C, Campos CA, Gutierrez OS, et al. Stent coronário de liga cobalto-cromo concebido no Brasil: achados histológicos preliminares em modelo experimental porcino. Rev Bras Cardiol Invasiva. 2007;15(4):378-85

63. Galon MZ, Takimura CK, Carvalho J, Chaves MJF, Lecchini S, Aiello VD, et al. Evolução temporal da proliferação neointimal após implante de dois tipos de stent farmacológico com polímeros biodegradáveis em modelo porcino: avaliação qualitativa por tomografia de coerência óptica sequencial. Ver Bras Cardiol Invasiva. 2012;20(4):413-9. 